\title{
IMPACT OF CONSUMER PERCEPTION ON PURCHASE INTENTION OF LUXURY PRODUCTS
}

\author{
S. Balakumaran ${ }^{1 \rrbracket}$, Dr. M. Ramkumar ${ }^{2}$ \\ ${ }^{1}$ Department of Business Administration, Annamalai University, Annamalainagar, India \\ ${ }^{2}$ Department of Business Administration, Kamarajar Government Arts College, Surandai, Tamilnadu, India
}

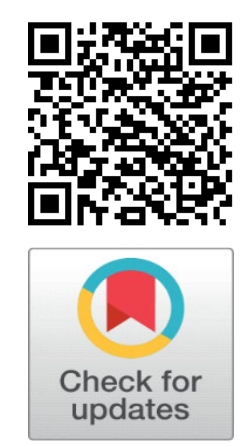

Received 21 July 2021

Accepted 07 August 2021

Published 30 September2021

CorrespondingAuthor

S. Balakumaran,

assistantprofessor.au@gmail.com

\section{DOI}

10.29121/granthaalayah.v9.i9.2021. 4149

Funding: This research received no specific grant from any funding agency in the public, commercial, or not-for-profit sectors.

Copyright: (C) 2021 The Author(s). This is an open access article distributed under the terms of the Creative Commons Attribution License, which permits unrestricted use, distribution, and reproduction in any medium, provided the original author and source are credited.

\section{ABSTRACT}

Though the current era has seen a huge extent of recession, due to the Covid 19 issue. But, the consumption of luxury products is seen to be remaining unchanged, even after the recession period. The concept of luxury can be seen in every place. It is the term which is commonly used by the individuals in their daily life. Luxury is the dream of every person for leading an exclusive lifestyle. It is the main element in the field of marketing management and also is a tagline in the campaigns of advertising and commercials. The study is done to examine the effect of consumer perception on the purchase intention of the luxury products. The respondents of the study are the consumers of luxury products residing at Chennai and they are selected through simple random sampling. The collection of data needed for the study is carried out using a questionnaire and the analysis is done by executing regression. The results of analysis show that the purchase intention was highly influenced by the consumer perception.

Keywords: Consumer Perception, Luxury Products, Purchase Intention

\section{INTRODUCTION}

One of the main constructs examined and analysed in the literature for marketing is the purchase intention. The scholars doing research in marketing regarding purchase intention evolve their research background from its connection with the buying behaviour. The term purchase intention refers to the implied promise made to one self for buying the things again and again when they go to the market.

This research has been regarding the influence of consumer perception on the purchase of luxury products. In this context, it becomes essential to analyse the behaviour of the individuals regarding the purchase of products which are of luxury brand. In countries like India, the social classes are categorized into rich and poor, upper and higher and so on. Regarding these disparities in the social classes, the purchase and consumption of the luxury products are done only by the elite classes. The luxury products marked its evolution in the 19th century, when many of the companies started the production of luxury products. Some brands of luxury products include Bylgari of Italy, Louis and Vuitton of France etc.

The luxury products sector has undergone massive changes in the last decade. The luxury products are selected by all the classes of society. The consumption pattern depends upon the perception of the consumers regarding the brand 
name, brand image, product quality, manufacturer's reputation and so on, regarding the luxury products. Hence, it is essential for the producers of the luxury brand products to consider the perception of the consumers while offering the luxury product in the market, in order to boost up their reputation, which in turn, would help to increase their sales.

\section{STATEMENT OF PROBLEM}

The current trend of consumption of the luxury products has changed to a great extent, due to the changes in the preference pattern of the consumers. Luxury products are regarded to be an indicator of modern and exclusive life style. But, still there are consumers who pay attention to their perception regarding the products before making a purchase. They tend to pay attention to the price, quality, reputation and so on before they actually buy the product. However, there are also still some companies which do not give preference to all these factors.

\section{NEED FOR THE STUDY}

The need for the study arises, when the companies producing luxury products, wish to understand better the perceptions of the consumers before purchasing the product. This study will be helpful for the marketing managers who desire to frame the strategies for the increased sales of their luxury products. It will help them to understand better the factors which the consumers perceive for the purchase of luxury items.

\section{OBJECTIVES}

The intention with which this research study has been undertaken is to identify the effect of consumer perception on the purchase intention of luxury products of the individuals.

\section{REVIEW OF LITERATURE}

Aggrawal and Manjrekar (2010) explored the effect of consumer perception on the buying behaviour of individuals with reference to the purchase of products of luxury in the retail sector for apparels. The study was done only in certain cities in India. The perception of the consumers regarding apparels can be considered as the outcomes of the changes in tastes and preferences and the cultural elements which the consumers consider. The major challenge for the marketing personnel is to understand the relation between the brands and the consumers, in particular, the features like materialism which is a strong driving force for the acquisition and consumption of particular brand products. The authors of this research study had examined the relation of consumer features like gender, materialistic level and nation of origin with the perception of brand. The consumers perceive that brands give them emotional (prestige, wealth, status) and utilitarian (low price, quality) advantages. This perception regarding the brand had got to affect the purchase intention of the consumers regarding the brand.

Joya et al. (2014) had done a study regarding the art world. They had examined the perception of the consumers regarding the way in which the stores of luxury brand became art institutions. The authors had done an ethnographic research regarding the perceptions of consumers regarding the flagship stores of Louis Vuitton and revealed that the stores for luxury products had turned out into hybrid institutions, which comprised of museums and art galleries. They had coined the 
word "M(Art)World" for capturing the crux of this artistical oriented strategy. The respondents considered the elegant architecture of the firm, lighting design and interior design. The merchandize of the store is artisanal, which is produced in association with the artists. The products meant for sale were kept at the side of the art, which gave importance for both the products and the art. The workers of the company acted as curators and gave knowledge and guidance and also products to the consumers for selling the products. The authors had analysed the ways in which the consumers of luxury products experience and assess the manner of operation of the luxury stores as a fashionable art institution.

Chattalas and Shukla (2015) examined the effect of value perceptions regarding the purchase intention of luxury products. The study was a comparison made amidst the developed markets. The subjective value for any product is made on the bases of the perceptions made by the consumers. The authors had made this study to analyse such effects of value perceptions on the purchase intention of luxury products. The study was done in two largest markets of luxury products; USA ad UK. The design of the study was cross-sectional. Data needed for the study was collected through a survey and analysis was carried out through SEM. The outcomes showed that, in both the nations, the perceptions regarding functional value influenced the purchase intention of luxury products. The consumers in US gave more importance to social value of the product and personal value of the product was given more significance by the consumers in UK. The results provide managers opportunities for strategic differentiation and brand positioning of their luxury brand in a crossnational context. The findings demonstrate that while the USA and the UK remain fairly similar on most macro cultural traits, consumer value perceptions differ significantly. Hence, a cautionary approach is advised in making generalised assumptions using national-level cultural indicators at consumer-level decision making.

AyselErcis and Celik (2018) studied the effect of the perceptions of value on the purchase intentions of luxury products with the role of consumer knowledge as the moderator. The aim of this study was to identify the effect of consumer's perception regarding value on their purchase intention of luxury products and also the way in which the consumer knowledge moderated the relation of consumer's perception of values with the purchase intention of luxury products. Data collection was done using a survey and the sample size was 271 . The respondents were the consumers of Bursa. The analysis of the data was done by executing SEM. The findings of analysis showed that perceptions of functional, personal and social values influenced the purchase intentions of luxury products by the consumers. The study also revealed the role played by the consumer knowledge as a moderator in the relation of functional and personal value perceptions and purchase intentions of luxury products. But, there was no moderation of consumer knowledge on the relation of social value with the purchase intention of luxury products.

Salehzadeh and Pool (2016) examined the perceived value and brand attitude and the purchase intention of the consumers regarding the luxury products of global brands. The aim of this paper was to investigate the way perceived value and brand attitude affected the purchase intention of the consumers regarding luxury products of global brands. After reviewing the literatures regarding the consumer behaviour, The authors had tested the relation amidst brand attitude, perceived value and the purchase intentions. The relation amidst the study variables was done by performing SEM analysis. The findings of the study revealed that the perceived value along with its dimensions were influenced positively by brand attitude. Additionally, the perceived values made by the consumers were found to be the 
antecedents of the consumer's purchase intention. The study was done in the context of a luxury firm of Iran.

\section{RESEARCH METHODOLOGY}

The study is performed to explore the effect of perceptions made by the consumers on the purchase of the luxury products. the respondents are the consumers of luxury products in Chennai. They are selected by means of simple random sampling and questionnaires are handed over to them for the purpose of data collection. The analysis of the data so collected is done by the execution of regression. Scale adopted from Salehzadeh and Pool (2016)

\section{ANALYSIS AND INTERPRETATION}

$\begin{array}{ccccc}\text { R } & \text { R Square } & \text { Adjusted R Square } & \text { F } & \text { Sig. } \\ .980(\mathrm{a}) & .960 & .956 & 238.150 & .000(\mathrm{a})\end{array}$

\section{Coefficients(a)}

\begin{tabular}{|c|c|c|c|c|c|}
\hline & \multicolumn{2}{|c|}{$\begin{array}{l}\text { Unstandardized } \\
\text { Coefficients }\end{array}$} & \multirow{2}{*}{$\begin{array}{c}\text { Standardized } \\
\text { Coefficients } \\
\text { Beta }\end{array}$} & \multirow[t]{2}{*}{$\mathbf{t}$} & \multirow[t]{2}{*}{ Sig. } \\
\hline & B & Std. Error & & & \\
\hline (Constant) & -.108 & .101 & & $\begin{array}{c}- \\
1.073\end{array}$ & .286 \\
\hline $\begin{array}{l}\text { Owning this luxury accessories } \\
\text { indicate a symbol of prestige }\end{array}$ & .078 & .022 & .115 & 3.571 & .001 \\
\hline $\begin{array}{l}\text { I would buy a luxury accessory just } \\
\text { because it has status }\end{array}$ & .053 & .038 & .055 & 1.416 & .160 \\
\hline $\begin{array}{l}\text { I would pay more for a luxury } \\
\text { accessory if it has status }\end{array}$ & .121 & .020 & .198 & 5.921 & .000 \\
\hline $\begin{array}{l}\text { During purchasing luxury } \\
\text { accessories, I feel the excitement of } \\
\text { the hunt }\end{array}$ & .206 & .033 & .229 & 6.323 & .000 \\
\hline $\begin{array}{l}\text { When in a bad mood I may buy } \\
\text { luxury accessories to enhance my } \\
\text { mood }\end{array}$ & -.017 & .028 & -.018 & -.585 & .560 \\
\hline $\begin{array}{l}\text { I purchase luxury accessories to } \\
\text { reflect my own image }\end{array}$ & .086 & .019 & .121 & 4.561 & .000 \\
\hline $\begin{array}{l}\text { The quality of a luxury accessory is } \\
\text { important to me }\end{array}$ & .191 & .026 & .222 & 7.426 & .000 \\
\hline $\begin{array}{l}\text { The luxury accessories superior } \\
\text { quality is my major reason for } \\
\text { purchasing them }\end{array}$ & .087 & .026 & .102 & 3.357 & .001 \\
\hline $\begin{array}{l}\text { I am very attracted to unique luxury } \\
\text { accessories }\end{array}$ & .237 & .024 & .348 & 9.688 & .000 \\
\hline
\end{tabular}

a Dependent Variable: Purchase Intention

The above table revealed a positive coefficient, which means that among all the statements of consumer perception were influence on the purchase intention of luxury product purchasers in Chennai. There was a positive relation found between consumer perception and purchase intention. $R$ value of this study was 0.903 and significant value of the study was 0.00 . Findings show that the purchase intention was highly influenced by the consumer perception. 


\section{CONCLUSION}

The products of luxurious nature are a symbol of leading a modern, prestigious and exclusive life style. People of the modern-day world go in search of such products which feed their desire of leading a luxurious life. They make the purchase of luxury products on the basis of their perceptions regarding those products. these value perceptions regarding the products made by the consumers have to be given importance by the producers, in order to satisfy the needs of the customers and also to boost up their sales and profit as well. Findings show that the purchase intention was highly influenced by the consumer perception.

\section{REFERENCES}

Amit Aggrawal and Dr. Pradip Manjrekar (2010) impact of consumer Perception on Buying Behavior in Apparel Retail Sector, with special reference to Selected Indian Cities; Thesis Submitted to the Padmashree Dr. D. Y. Patil University, Department of Business Management in partial fulfilment of the requirements for the award of the Degree of doctor of philosophy in business management. Retrieved from http://www.dypatil.edu/schools/management/wpcontent/uploads/2015/10/AmitAggrawal-2010-Ph.D.pdf

Annamma Joya, Jeff Jianfeng Wang, Tsang-Sing Chan, John F. Sherry Jr. and Geng Cui (2014); M(Art)Worlds: Consumer Perceptions of How Luxury Brand Stores Become Art Institutions; Journal of Retailing 90 (3, 2014) 347-364. Retrieved from https://doi.org/10.1016/j.jretai.2014.01.002

AyselErcis and Bilal Celik (2018) Impact of value perceptions on luxury purchase intentions: moderating role of Consumer knowledge; PressAcademia Procedia, V.7, p.52-56. Retrieved from https://doi.org/10.17261/Pressacademia.2018.855

Michael Chattalas and Paurav Shukla (2015) Impact of value perceptions on luxury purchase intentions: a developed market comparison; June 2015; Luxury Research J 1(1): 40-57. https://doi.org/10.1504/LRJ.2015.069806

Reza Salehzadeh and JavadKhzaei Pool (2016) Brand Attitude and Perceived Value and Purchase Intention toward Global Luxury Brands Journal of International Consumer Marketing Volume 29, 2017 - Issue 2. https://doi.org/10.1080/08961530.2016.1236311 